\title{
Changes of Ornithine Transcarbamylase Activity with Age in the Chicken
}

\author{
Soichi Tsuji and Toyokazu Fukushima \\ Faculty of Agriculture, Kobe University, Kobe-shi 657
}

(Received July 1, 1974)

\begin{abstract}
Changes of ornithine transcarbamylase (OTC) activities of the chicken kidney with age were investigated using normal (A) and high activity (B) lines of White Leghorn breed. Embryos of 18th day of incubation of both lines, chicks of 2 to 30 days of age in the line $\mathrm{A}$, and chicks of up to 120 days of age in the line $\mathrm{B}$, were subjected to investigation. In the control line A, 95\% of the chicks showed a low level of OTC, less than 10 units, at 30 days of age. In the chicks of high activity group which consisted $25 \%$ of the line B, OTC level was already high from the embryonic life. Chicks of this group showed a characteristic change of the enzyme activity after hatch, being high at 2 and 7 days of age and falling thereafter through 120 days of age. In both lines OTC level in the female seemed to be slightly higher than that of the male.
\end{abstract}

None of the enzymes of urea biosynthesis, except trace of arginase (EC 3.5.3.1), have been found in the chicken liver ${ }^{1,2)}$. On the other hand, in the chicken kidney these enzymes have been found in moderate amount ${ }^{2}$.

Ornithine transcarbamylase (OTC) (EC 2.1.3.3), one of urea cycle enzymes, is widely distributed in microorganisms ${ }^{3,4)}$, plant ${ }^{5)}$ and ureoteric animals ${ }^{6,7,8)}$. A large number of studies have been made on purification and characterization of this enzyme $e^{4,5,6,7,8)}$. However the enzymatic activity is relatively low in the chicken kidney in comparison with certain microorganisms and livers from ureoteric animals ${ }^{2}$. Because of this low enzymatic activity, no systematic studies of chicken OTC have been carried out.

As described in the previous report ${ }^{9}$, the author has found that chicks of one line of white Leghorn breed had unusually high level of OTC and that the enzymatic activity was ten to twenty fold as high as that of the other chicken breeds.

The purpose of the present study was to investigate the changes of the level of OTC activity during the embryonic development and growth of the chick as well as relations to the sex.

\section{Materials and Methods}

\section{Chicks}

Chicks and embryos of two White Leghorn lines, i.e., White Leghorn A and White Leghorn $B$, were used in this experiment and these lines were the same ones used in the previous study9). Embryos of 18 th day of incubation and chicks of 2,7, and 30 days of age of both lines and 120 days of age of White Leghorn $B$ line were used in this study. Newly hatched chicks were not fed for the first 2 days. They were then fed with a commercial chick starter ad libitum. The number of embryos and chicks used in the experiments is shown in the Table 1 and Table 2. 


\section{Preparation of Homogenates and OTC Assay}

Embryos and chicks of selected ages were sacrificed by decapitation. The kidneys were excised rapidly and immediately homogenized with a Teflon pestle homogenizer in 19 volumes of 0.1 per cent cetyl-trimethyl-ammonium-bromide. Supernatant layer of centrifuged homogenate was used for the enzyme assay, which was carried out by measuring the amount of citrulline synthesized with the same system as in the previous repor ${ }^{99}$. Citrulline was determined by the method of HunNinghake and Grisolia ${ }^{10 \%}$.

\section{Results and Discussions}

\section{Changes of OTC Activity during Development and Growth}

OTC activity of chicks was quite variable and that of cell-free extract of White Leghorn A line chick kidney ranged from null to 61.3 units. As shown in Table 1, the enzymatic level of most of the embryos and chicks tested in this experiment was less than 10 units, and was in accordance with the lower levels reported by TAMIR and RATNER ${ }^{2}$. The percentage in number of embryos and 2 day-old chicks having the enzymatic activity between null and 10 units was 74 and 62 , respectively, and that of 7 day-old and 30 day-old chicks was 95 and 94 , respectively. A few chicks having slightly high level of OTC activity were found in $A$ line. In this line at 2 days of age the percentage of chicks having the enzymatic activity from 10 to 20,20 to 40 , and 30 to 50 units were 24,10 , and 4 , respectively. The highest activity of the enzyme, 61.3 units, was observed at 30 days of age.

In contrast to the level of OTC activity of White Leghorn A line chicks, that of B line chicks was more variable and higher as reported in the previous report ${ }^{9}$. The enzymatic activity of B line chicks shown in Table 2 was found between null and 310 units.

In 2 day-old chicks, the enzymatic activities ranged from 140 to 290 units for the high activity group and those ranged from null to 40 units for the low activity group were observed. The enzyme concentration of the high activity group changed remarkably during development and growth. The mode of OTC activity of embryos was 100 units and it increased thereafter to

Table 1. The frequency of the level of ornithine transcarbamylase activities in White Leghorn A line

\begin{tabular}{|c|c|c|c|c|c|c|c|c|c|c|c|c|}
\hline \multirow{4}{*}{$\begin{array}{c}\text { Enzymatic } \\
\text { activity } \\
\text { Units* }\end{array}$} & \multicolumn{12}{|c|}{ Frequency, number of chicks and embryos } \\
\hline & \multirow{2}{*}{\multicolumn{3}{|c|}{ 18-day embryo }} & \multicolumn{9}{|c|}{ Age of chicks, days } \\
\hline & & & & \multicolumn{2}{|c|}{2} & \multicolumn{3}{|c|}{7} & \multicolumn{3}{|c|}{30} & \multirow[b]{2}{*}{$\% * *$} \\
\hline & $\beta$ & o & $\% * *$ & 令 & q & $\% * *$ & $\hat{\delta}$ & 우 & $\% * *$ & 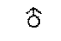 & o & \\
\hline $0-10$ & 73 & 45 & $(73.8)$ & 74 & 48 & $(61.6)$ & 89 & 98 & $(94.9)$ & 108 & 85 & $(93.7)$ \\
\hline $10-20$ & 9 & 30 & $(24.4)$ & 12 & 36 & $(24.2)$ & 4 & 1 & $(2.5)$ & 5 & & $(2.4)$ \\
\hline $20-30$ & 2 & 1 & $(1.9)$ & 5 & 15 & $(10.1)$ & & & & 5 & & $(2.4)$ \\
\hline $30-40$ & & & & 4 & 1 & $(2.5)$ & & & & 1 & 1 & $(1.0)$ \\
\hline $40-50$ & & & & 3 & & $(1.5)$ & 1 & 1 & $(1.0)$ & & & \\
\hline $50-60$ & & & & & & & 3 & & $(1.5)$ & & & \\
\hline $60-70$ & & & & & & & & & & & 1 & $(0.5)$ \\
\hline Total & 84 & 76 & & 98 & 100 & & 97 & 100 & & 119 & 87 & \\
\hline
\end{tabular}

* $\mu$ moles citrulline formed/hr/gm of kidney

** Percentage on the sum of the number of male and female chicks 
Tsuji and Fukushma

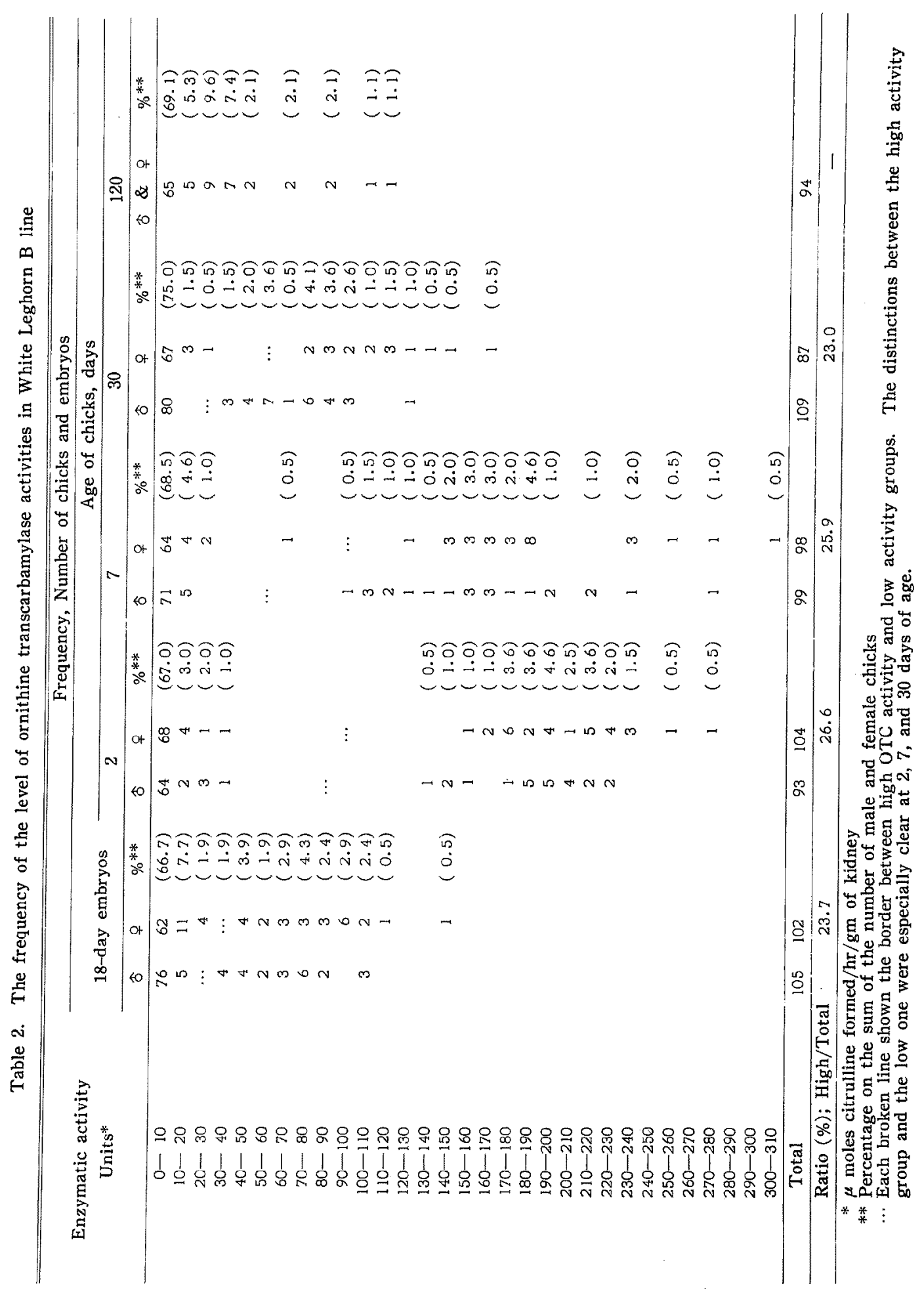




\section{Changes of Chicken OTC with Age}

about 210 units in 2 day-old and then slightly decreased to about 200 units in 7 day-old chicks. After that time, OTC activity declined rapidly and the mode of the enzymatic activity fell to the embryonic level in 30 day-old chicks. Furthermore, the decline was continued throughout the experimental period.

In low activity group of $B$ line, any noticeable change of OTC activity was not observed during the development and growth. Either in high activity group of B line or A line, changes in chick kidney OTC during growth had similar tendency in which the highest enzymatic activity was observed at hatching and it decreased slowly until 7 days and then rapidly decreased by 30 days of age.

It is well known that the enzymes concerning ornithine-urea cycle of mammals are low in fetal liver and reach adult level by 3 to 5 weeks of age ${ }^{11}$. Difference of the changes of OTC activity between chickens and mammals during development and growth have been suggested and the regulatory mechanisms might also be different between the two. The decrease in accumulation of OTC in chicks after one week of age suggested that the enzyme might have different roles on metabolism from that of mammals having ornithine-urea cycle.

Similar tendency of OTC of chick kidney has been reported in the formation of serum alkaline phosphatase (EC 3.1.3.1) of chicken during growth ${ }^{12}$.

\section{Sex Difference of OTC}

As shown in Tables 1 and 2, a little difference by sex can be noted in the distribution of frequency of the levels of OTC activity. In White Leghorn A line chicks, the difference of the enzymatic activity between two sexes was observed in embryos and 2 day-old chicks. Chicks and embryos having the enzymatic activity less than 10 units were of greater proportion in males than in females.

In the low activity group of B line, similar tendency was observed in all ages except 2 day-old. A slight difference appeared between two sexes in all ages of the high activity group of $\mathrm{B}$ line, in which the mode of OTC activity in females was higher than that of males. In the high activity group of 2 day-old chicks, the levels of OTC activity of male chicks were 140 to 220 units and those of the female were 160 to 270 units.

In the rat the time of appearance of the sex difference in the ornithine aminotransferase (EC 2.6.1.3) activity of the kidney coincided with the time of sexual maturity, indicating that the difference might be hormonally controlled ${ }^{13}$. On the other hand, the sex difference of chicken kidney OTC might occur independent of the time of sexual maturity, since the difference has been observed as early as in embryonic life. The factors relating to the sex difference of chicken kidney OTC level have not been revealed.

Consistent Appearance of Two Population of High or Low OTC Activity throughout Experimental Period.

As cited above, enzymatic activities in the kidney of White Leghorn B line chicks were more variable and higher. As shown in Table 2, the population of 2 and 7 day-old chicks can be classified into two groups based upon the levels of the enzyme. In 2 day-old chicks, 73 per cent of chicks had lower enzymatic activity ranging from null to 40 units and the remaining chicks had high OTC activity ranging from 140 to 280 units. Similar tendency was observed in 7 day-old chicks in which 74 per cent of chicks had low and the remainder had high enzymatic activities. The ratio of the population of high and low OTC activity remained one to three at these ages. Embryos and chicks of 30 and 120 day-old could not be divided clearly into high or 


\section{Tsuj1 and Fukushima}

low activity group, since the enzymatic activity at these ages were lower than that of 2 or 7 day-old chicks. But in male embryos, 81 embryos had the enzymatic activity below 30 units and 24 embryos had the enzymatic activity ranging from 40 to 110 units. On the other hand, 77 embryos had the enzymatic activity below 40 units and 25 embryos had enzymatic activity ranging from 50 to 150 units. It may be considered that the embryos having the enzymatic activity below 30 units in males and 40 units in females are low activity group and the remainders belong to high active group. From these observations, it has been suggested that 76.3 per cent of embryos had lower OTC activity and 23.7 per cent of embryos had a higher OTC activity and the ratio of the former to the latter was three to one. Similar tendency was observed in 30 day-old chicks. It has been observed that 77 per cent of chicks had lower OTC activity and 23 per cent of chicks had higher OTC activity and the ratio of the former to the latter was also three to one. In 120 day-old chicks, such tendency has not appeared clearly, due to small number of chicks available in this experiment. The data demonstrated that the ratio of the two populations, high and low OTC activity, held a constant ratio of three to one throughout this experimental period.

The results mentioned above support the concept which was proposed previously that the high kidney OTC activity was found in the genetic variant of chicks.

The authors wish to thank Ishii Layer Research Farm, Ishii-Cho, Tokushima-ken, for providing the chicks and embryos to carry out this work.

\section{References}

1) Mora, J., J. Martuscelli, J. Ortiz-Pineda, and G. Soberon, Biochem J 96: 28-35. 1965.

2) TAmiR, H., and S. Ratner, Arch Biochem Biophys 102: 249-258. 1963.

3) Grindie, M., and R.H. Davis, Genet Res Camb 15: 99-107. 1970.

4) Rogers, P., and G. D. Novelly, Arch Biochem Biophys 96: 398-407. 1962.

5) Klezkowski, K., and P.P. Cohen, Arch Biochem Biophys 107: 271-278. 1964.

6) Joseph, R. L., D.C. Watts, and E. Baldwin, Comp Biochem Physiol 11: 119-129. 1964.

7) Marshall, M., and P. P. Cohen, J Biol Chem 247: 1641-1653. 1972.

8) ReichaRd, P., Acta Chem Scand 11: 523-536. 1957.

9) Tsujs, S., Jap J Zootech Sci 45: 503-510. 1974.

10) Hunninghake, D., and S. Grisolia, Anal Biochem 16: 200-205. 1966.

11) Jones, M. E., A. D. Anderson, C. Anderson, and S. Hodes, Arch Biochem Biophys 95: 499507. 1961.

12) Wilcox, F. H., Poultry Sci 45: 776-784. 1965.

13) Herzfeld, A., and W. E. Knox, J Biol Chem 243: 3327-3332. 1966. 


\section{ニワトリ腎臓 Ornithine transcarbamylase の成長に伴う変動}

$$
\text { 过荘一・福島鄷一 }
$$

神戸大学農学部, 神戸市 657

\begin{abstract}
著者はニワトリの腎淢に若千存在する尿紫合成系酵素 のうちのーつである Ornithin transcarbamylase (OTC) 活性の品種間に括ける差異を検討し, White Leghorn 種

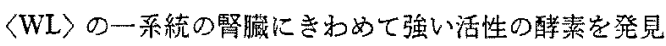
した.そこで,この活性の強い留䁍 OTC它としてそ の成長に伴う変動について検討した，供試したニワトリ 品種は前報に括けると同様, WL-A 系とWL-B 系の2 系統で，前省はOTC活性が垈く，後者には低活性と高 活性の OTCをそれぞれ有する個体が共存している。 WL-A 系ではろ化前 18 日目〉の脴加ら 30 日令のヒナに ついて，WL-B系では胚から120日令までのヒナについ て検討した，低い活性定有するWL-A 系では大多数の
\end{abstract}

個体ふ10 Unit 以下で，その此率は 2 日令のヒナと肧で 62\%と74\%であった．この比率はその後增加し，30日 令のヒナでは $95 \%$ 以上となった。全体としては 2 日令に おける本醉素の活性功最も高く、その後低下した, WL-B 采の低活性の個体群の成長に伴う变動は顥著でないが, 高い活性を有する個体群ではWL-A 系と同様に2 日令 のヒナでとの活珄が最も高く，以後徐々に低下した。本 酵素の活性は性による差が若干みとわられ，此倠の活性が

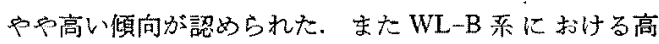
活性群と低活性群の出現比率はヒナの日令と関係なく一 定の傾向がみとめられた。 